\title{
Relative Timing of Uplift along the Zagros Mountain Front Flexure Constrained by Geomorphic Indices and Landscape Modelling, Kurdistan Region of Iraq
}

5 Mjahid Zebari ${ }^{1.2}$, Christoph Grützner ${ }^{1}$, Payman Navabpour ${ }^{1}$, Kamil Ustaszewski $^{1}$

${ }^{1}$ Institute of Geological Sciences, Friedrich-Schiller-University Jena, Jena, 07749, Germany.

${ }^{2}$ Geology Department, Salahaddin University-Erbil, Erbil, 44002, Kurdistan Region of Iraq.

Correspondence to: Mjahid Zebari (mjahid.zebari@uni-jena.de)

Supplementary material 


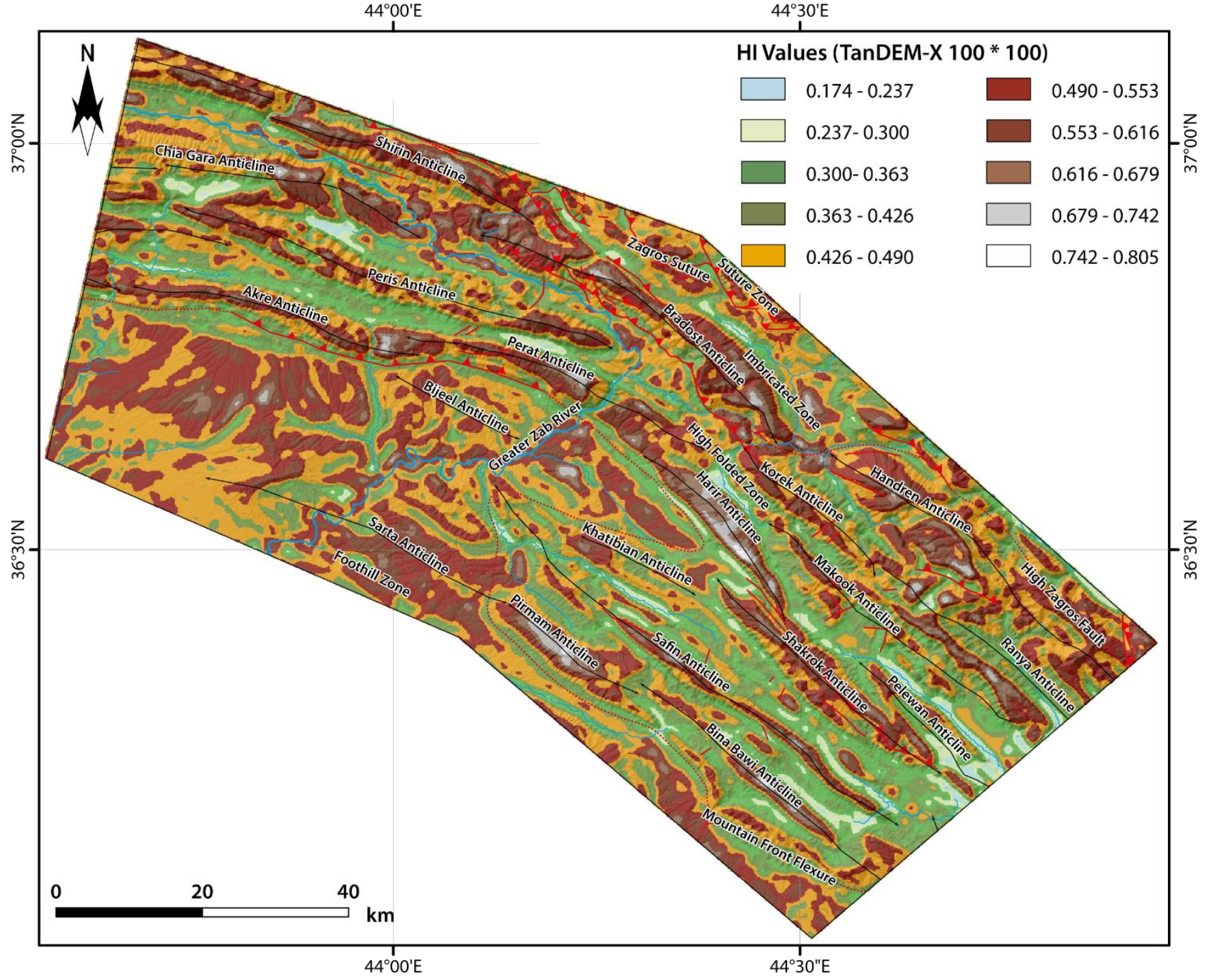

S1: Hypsometric integral (HI) calculated for TanDEM-X with $100 * 100$ cell $(1.2 * 1.2 \mathrm{~km})$ moving window. 


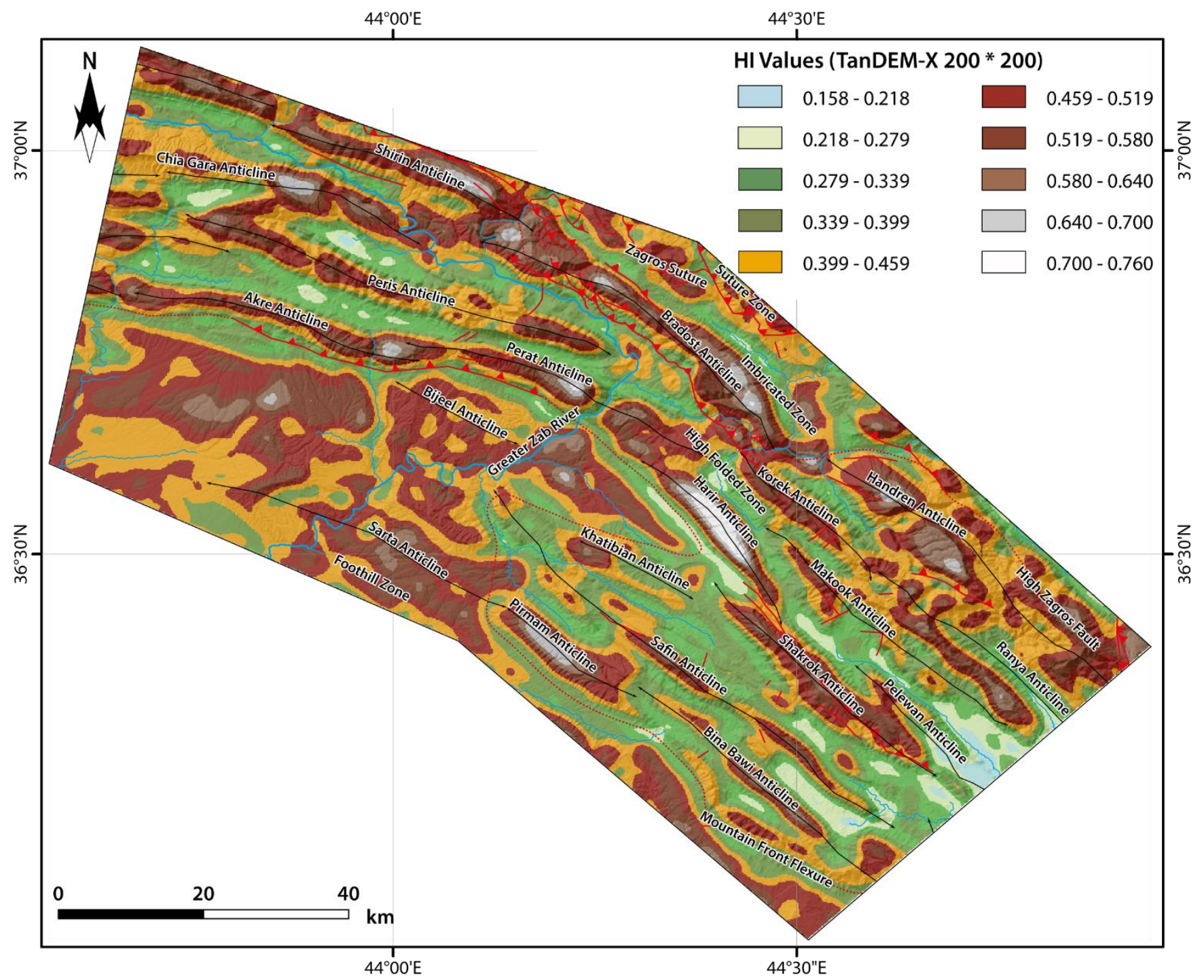

S2: Hypsometric integral (HI) calculated for TanDEM-X with $200 * 200$ cell $(2.4 * 2.4 \mathrm{~km})$ moving window. 


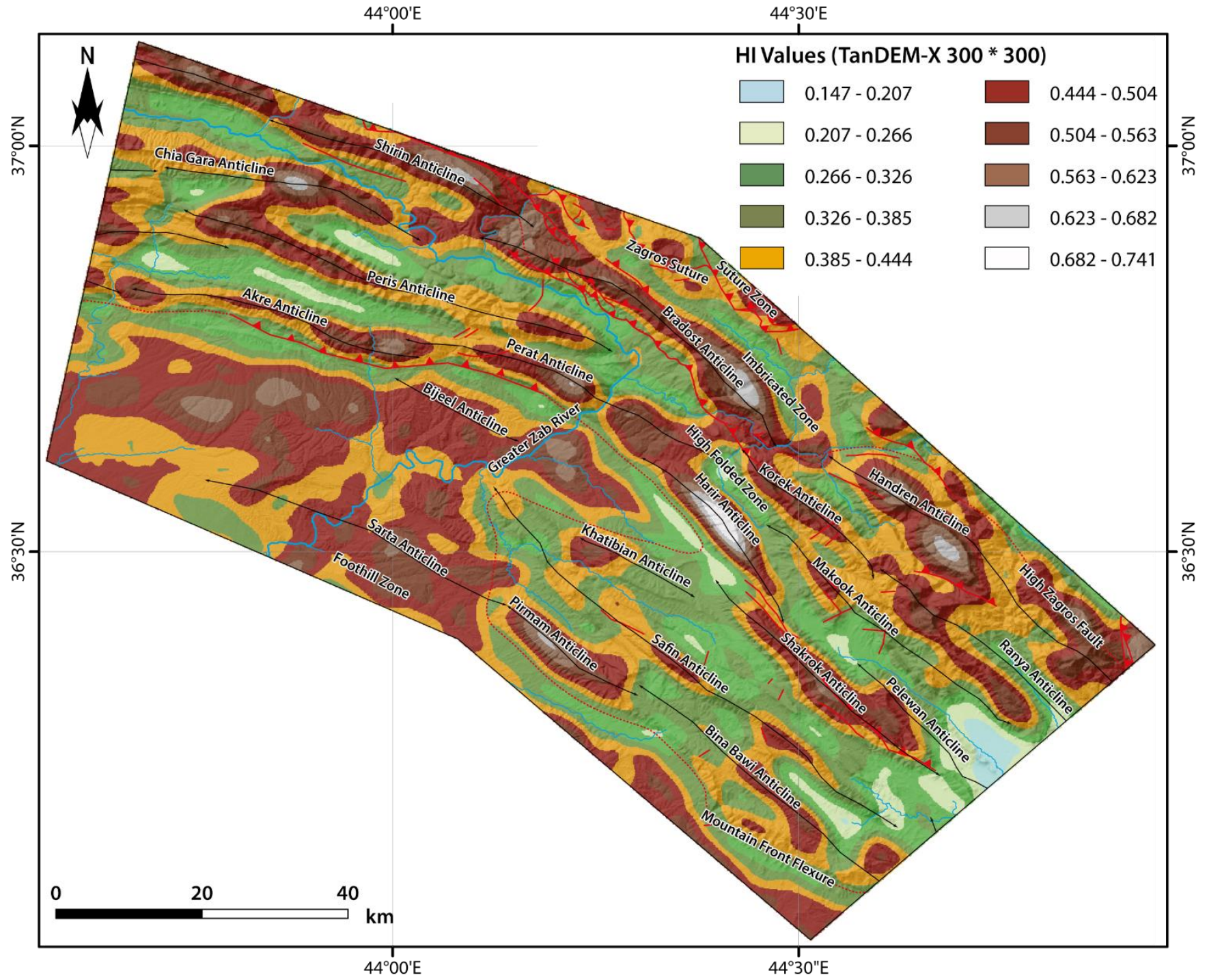

S3: Hypsometric integral (HI) calculated for TanDEM-X with $300 * 300$ cell $(3.6 * 3.6 \mathrm{~km})$ moving window. 


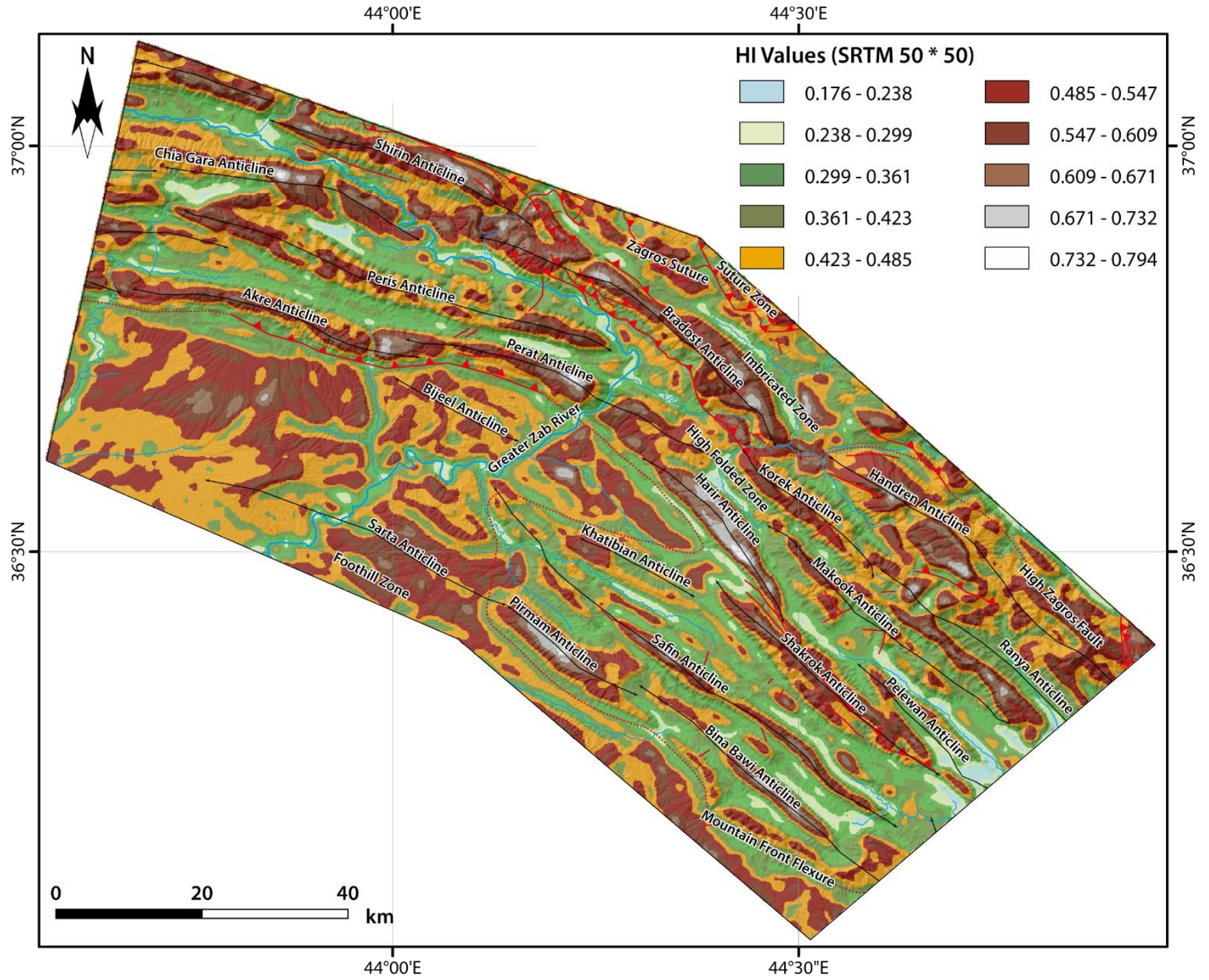

S4: Hypsometric integral (HI) calculated for SRTM with $50 * 50$ cell $(1.5 * 1.5 \mathrm{~km})$ moving window. 


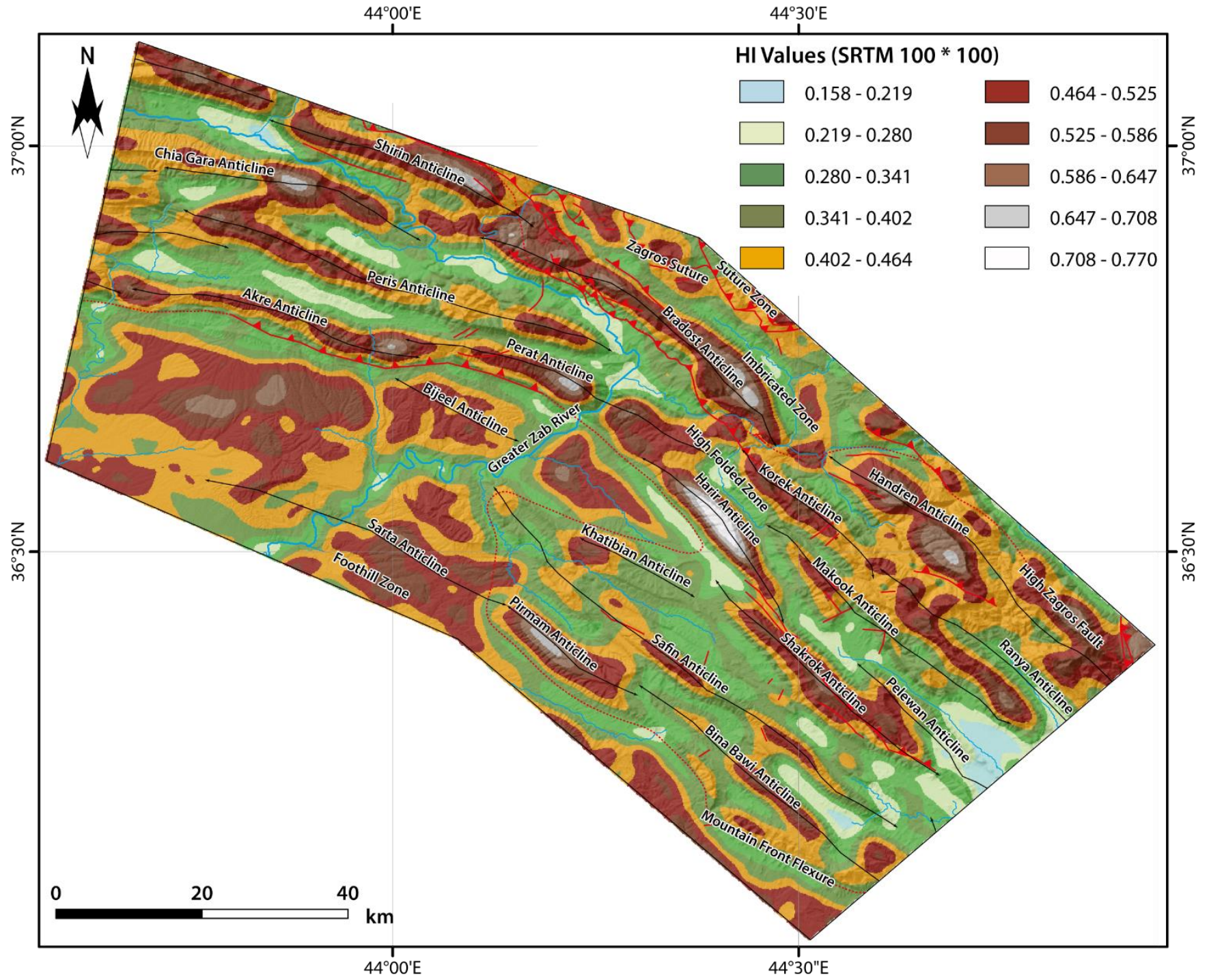

S5: Hypsometric integral (HI) calculated for SRTM with $100 * 100$ cell $(3 * 3 \mathrm{~km})$ moving window. 


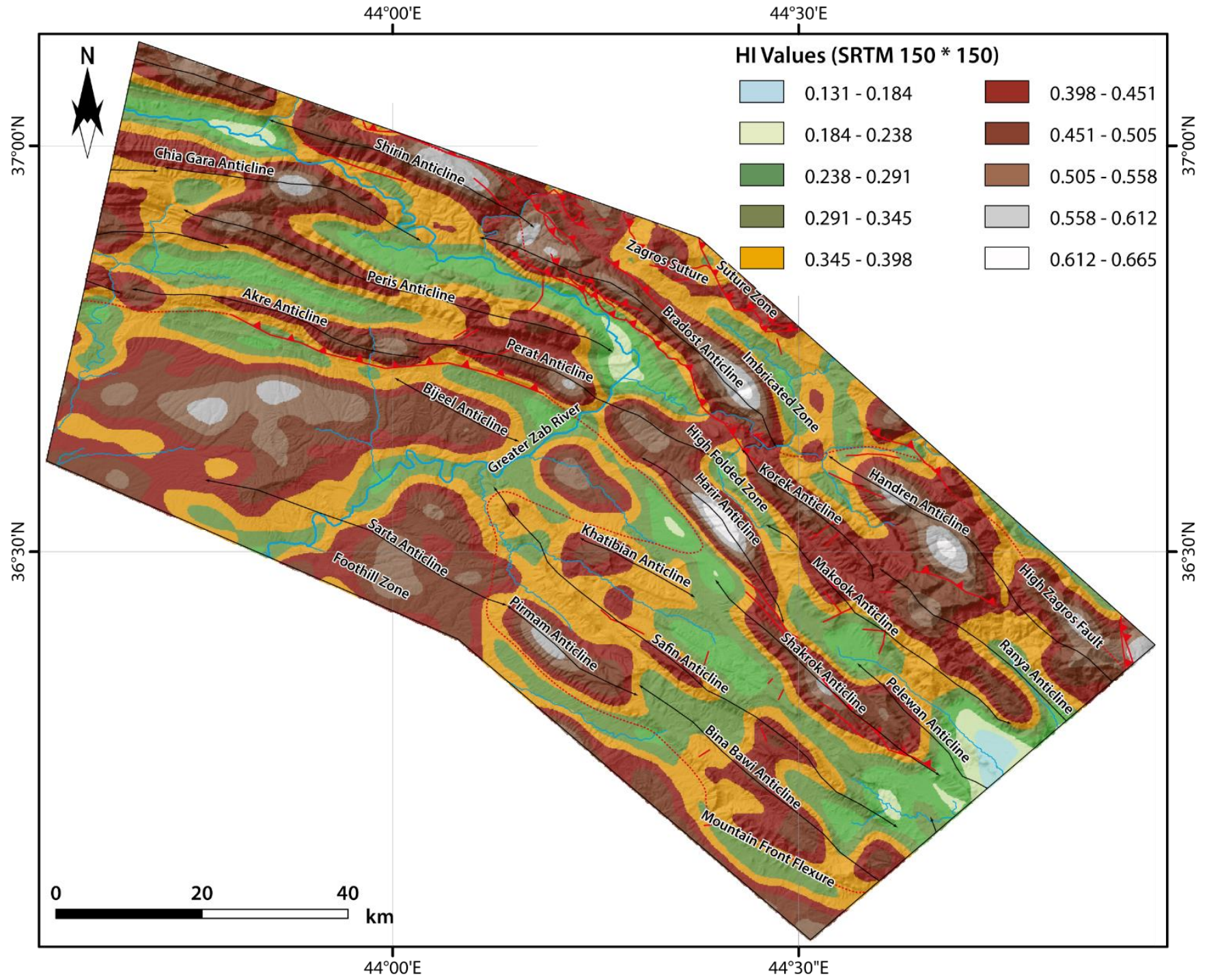

S6: Hypsometric integral (HI) calculated for SRTM with $150 * 150$ cell $(4.5 * 4.5 \mathrm{~km})$ moving window. 


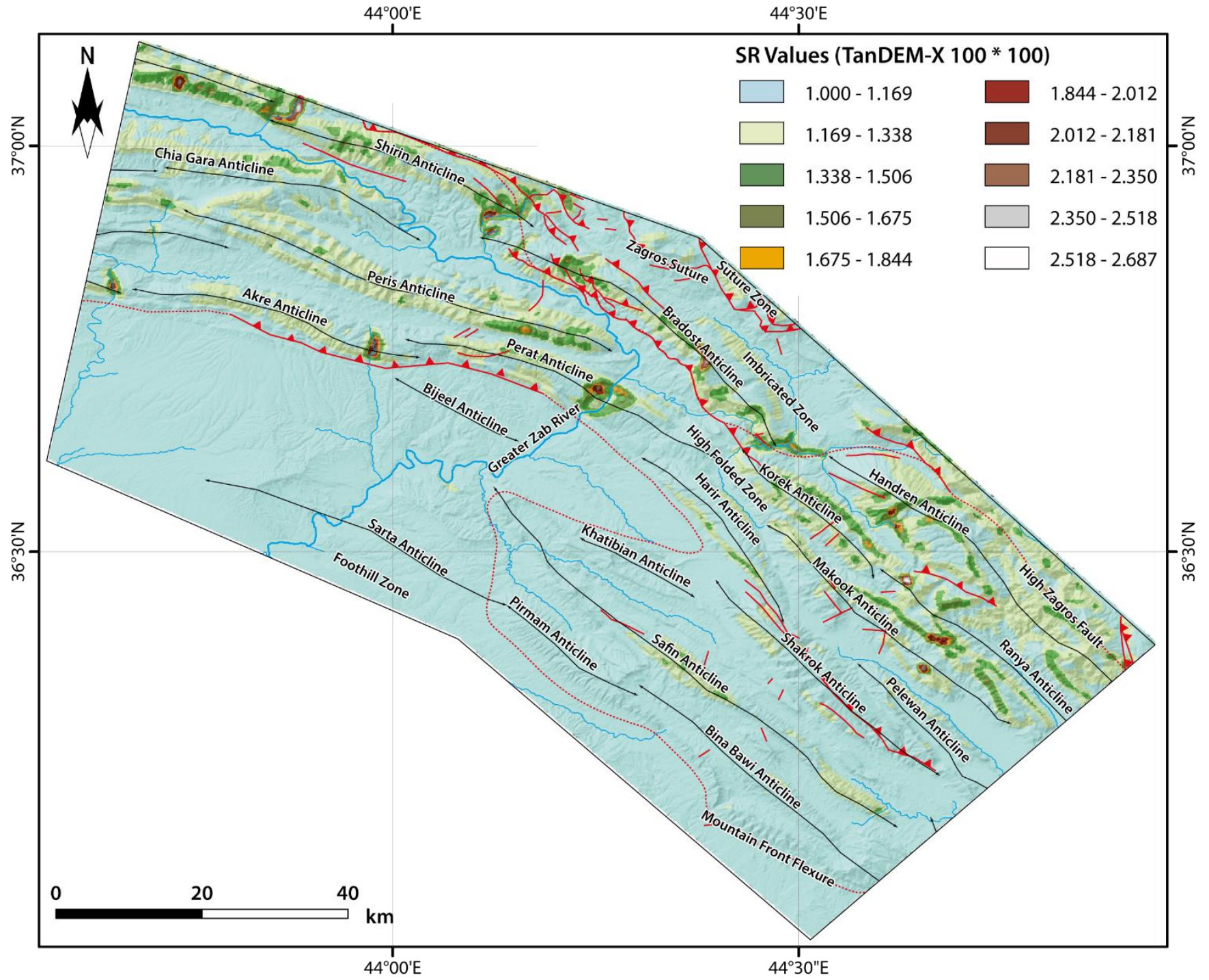

S7: Surface roughness (SR) calculated for TanDEM-X with $100 * 100$ cell $(1.2 * 1.2 \mathrm{~km})$ moving window. 


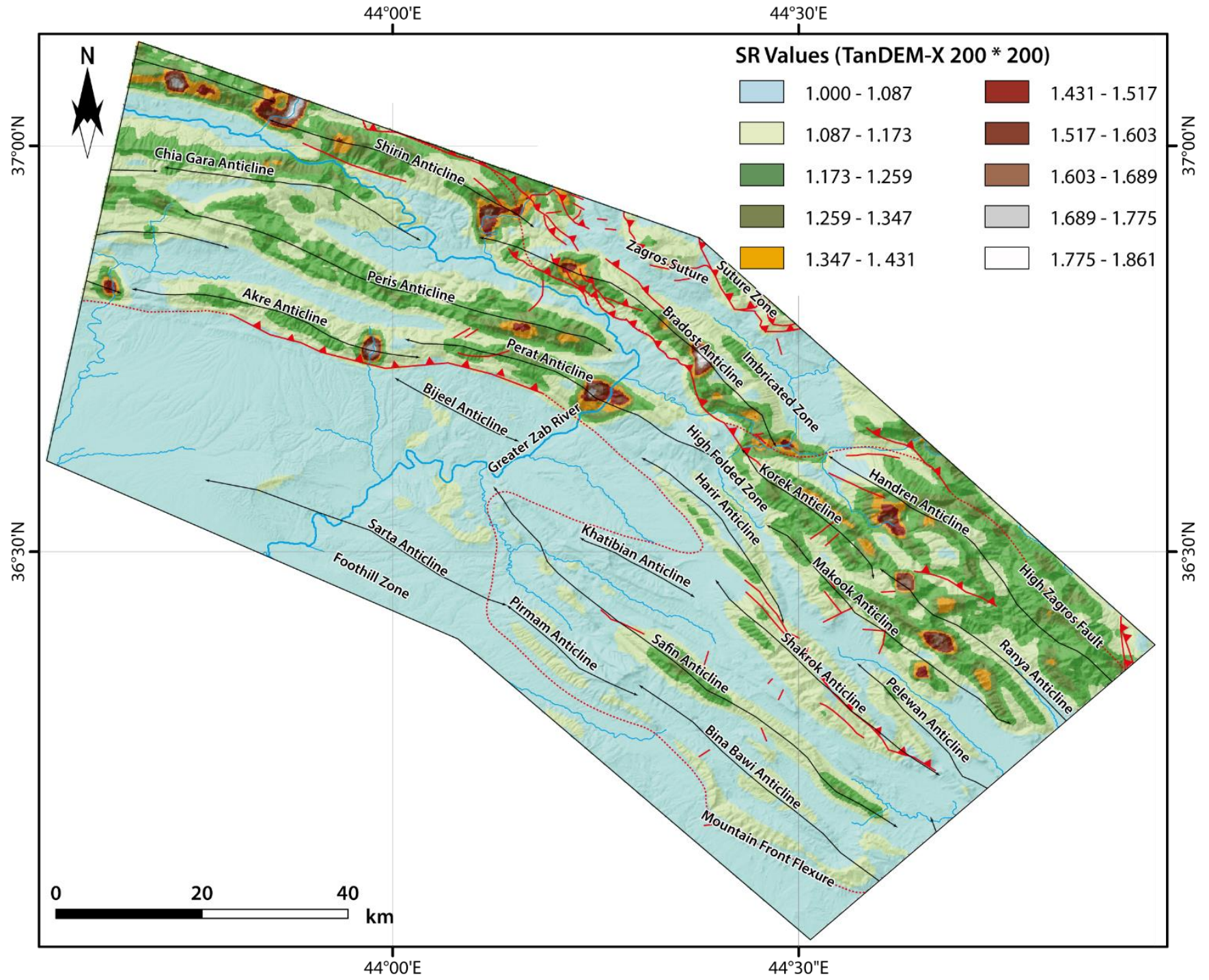

S8: Surface roughness (SR) calculated for TanDEM-X with $200 * 200$ cell $(2.4 * 2.4 \mathrm{~km})$ moving window. 


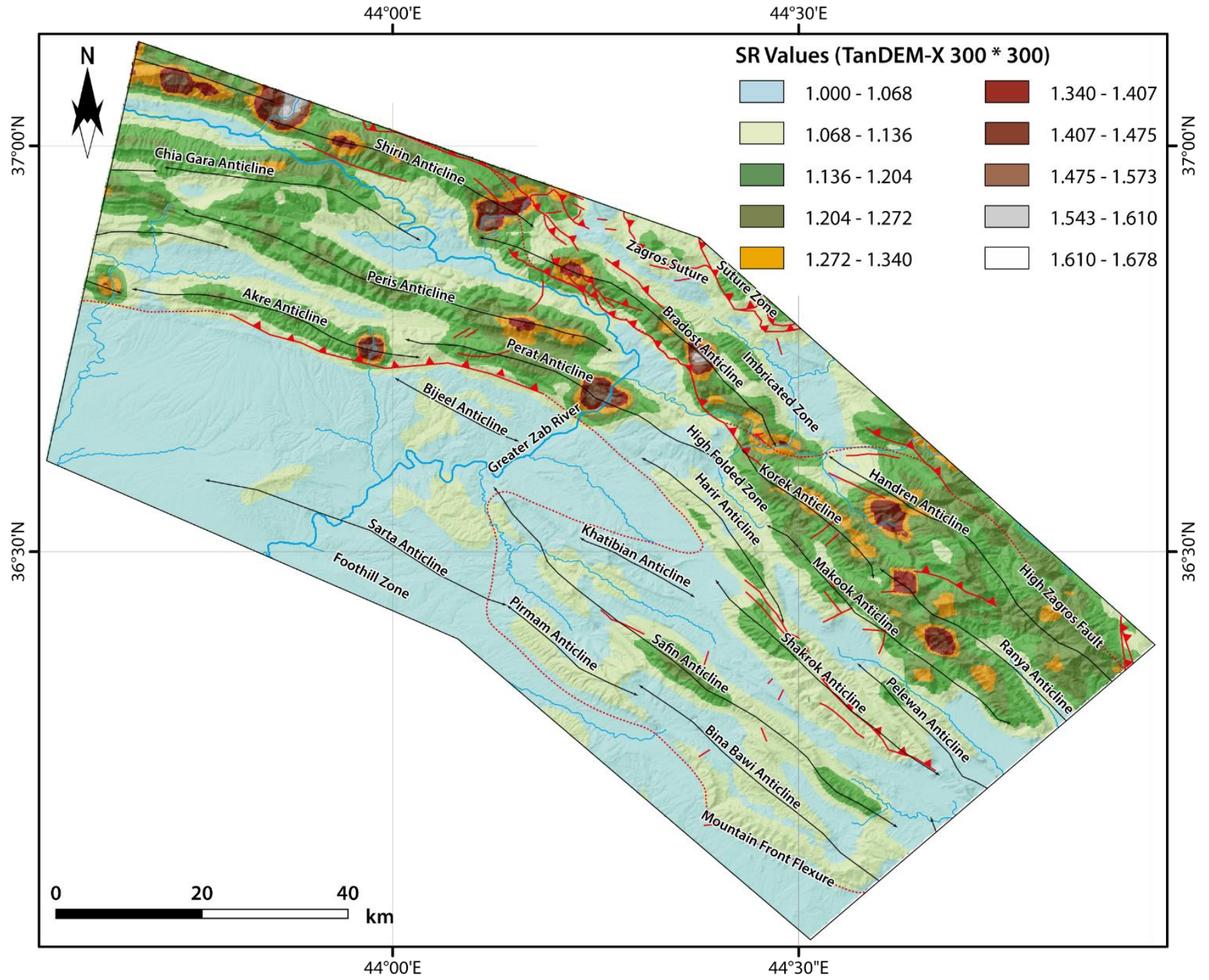

S9: Surface roughness (SR) calculated for TanDEM-X with $300 * 300$ cell $(3.6 * 3.6 \mathrm{~km})$ moving window. 


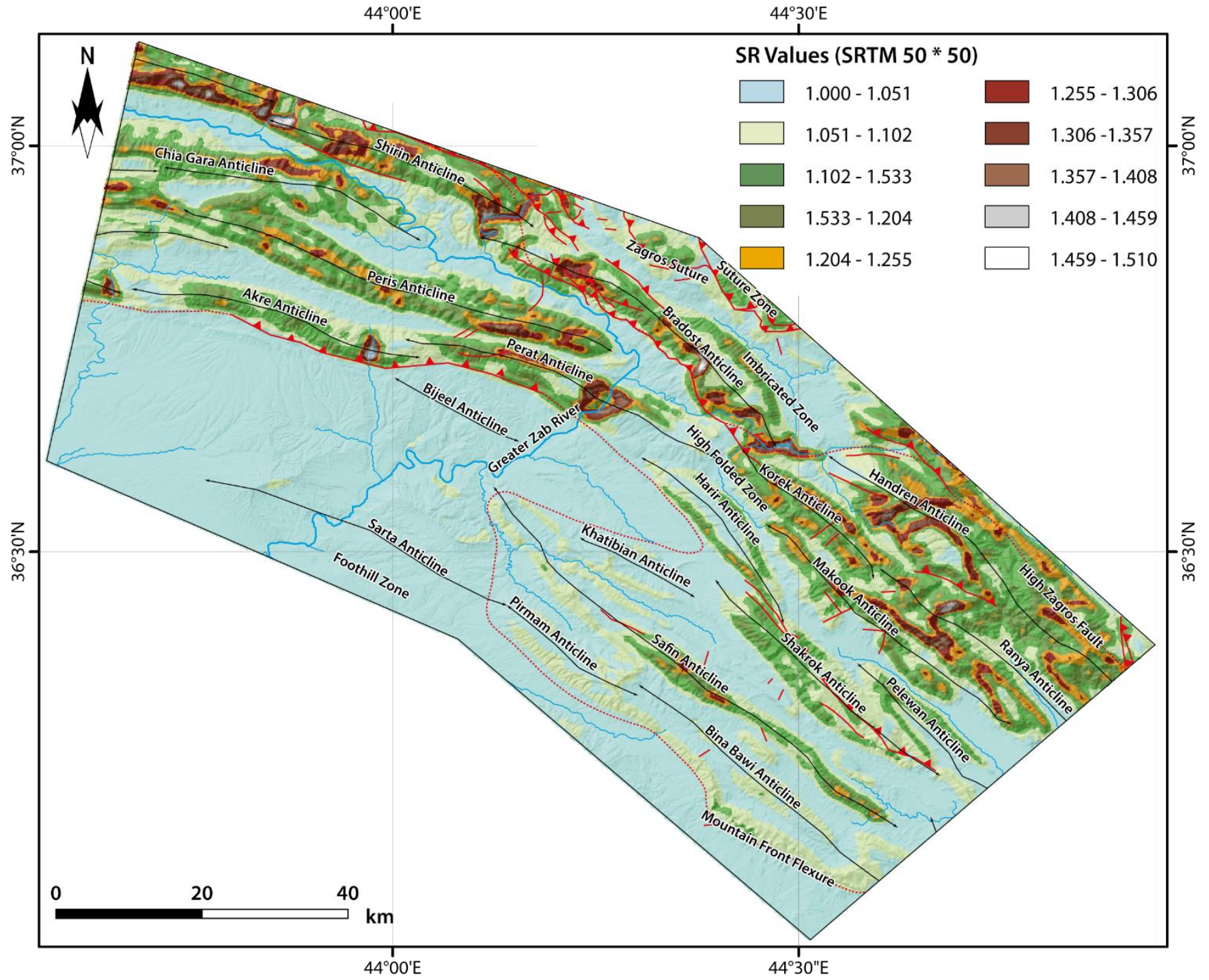

S10: Surface roughness (SR) calculated for SRTM with $50 * 50$ cell $(1.5 * 1.5 \mathrm{~km})$ moving window. 


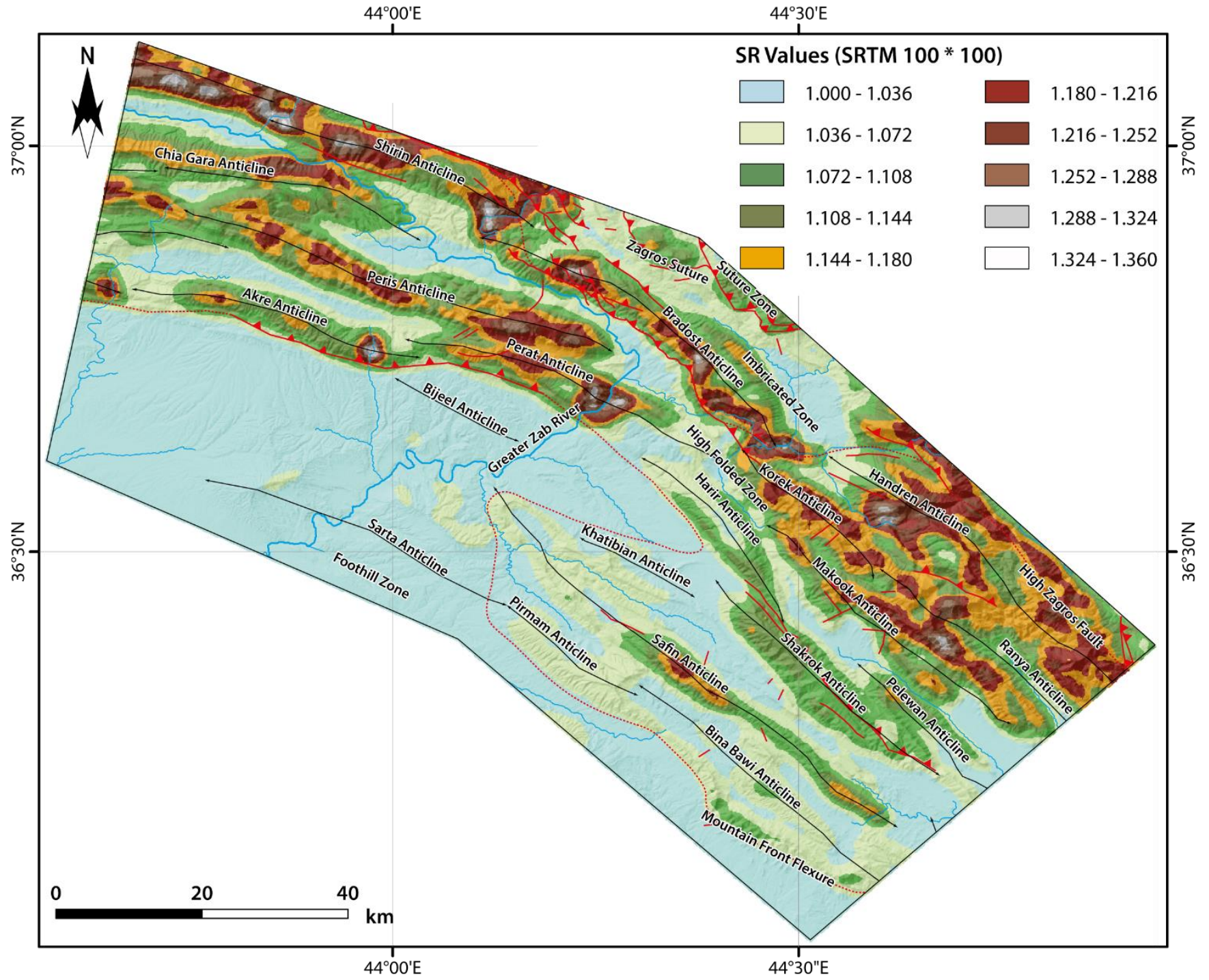

S11: Surface roughness (SR) calculated for SRTM with $100 * 100$ cell $(3 * 3 \mathrm{~km})$ moving window. 


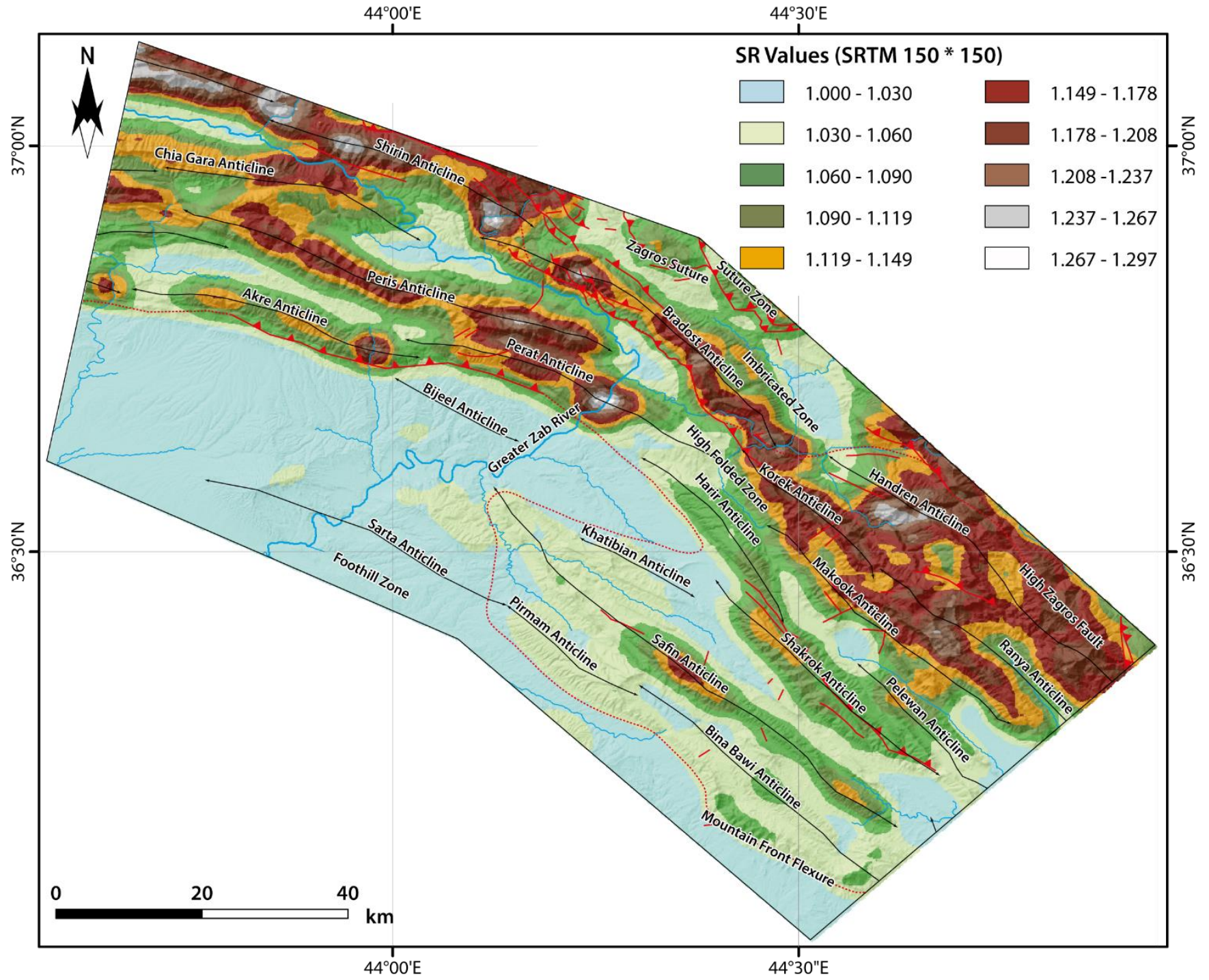

S12: Surface roughness (SR) calculated for SRTM with $150 * 150$ cell $(4.5 * 4.5 \mathrm{~km})$ moving window. 


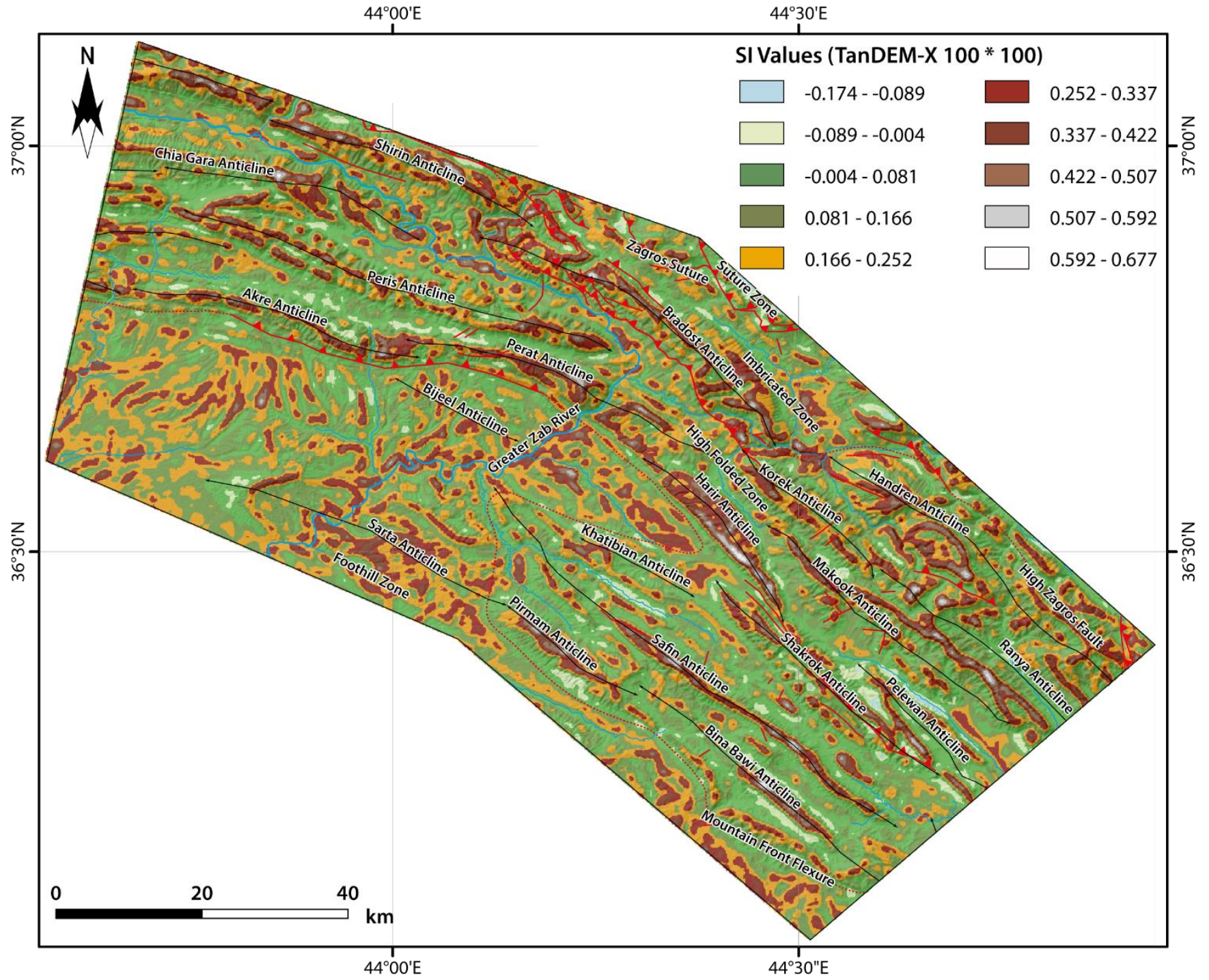

S13: Surface index $(\mathrm{SI})$ calculated for TanDEM-X with $100 * 100$ cell $(1.2 * 1.2 \mathrm{~km})$ moving window. 


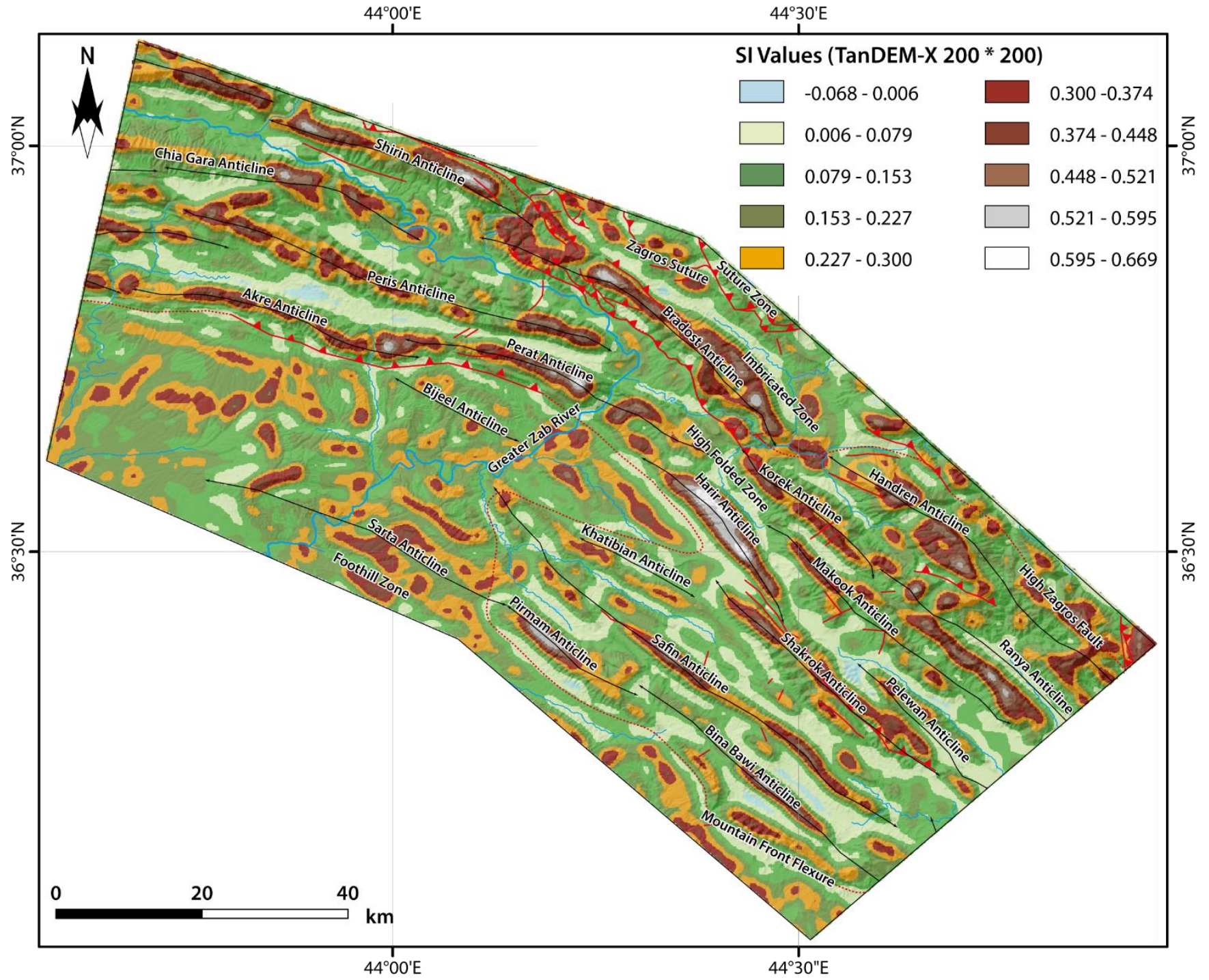

S14: Surface index (SI) calculated for TanDEM-X with $200 * 200$ cell $(2.4 * 2.4 \mathrm{~km})$ moving window. 


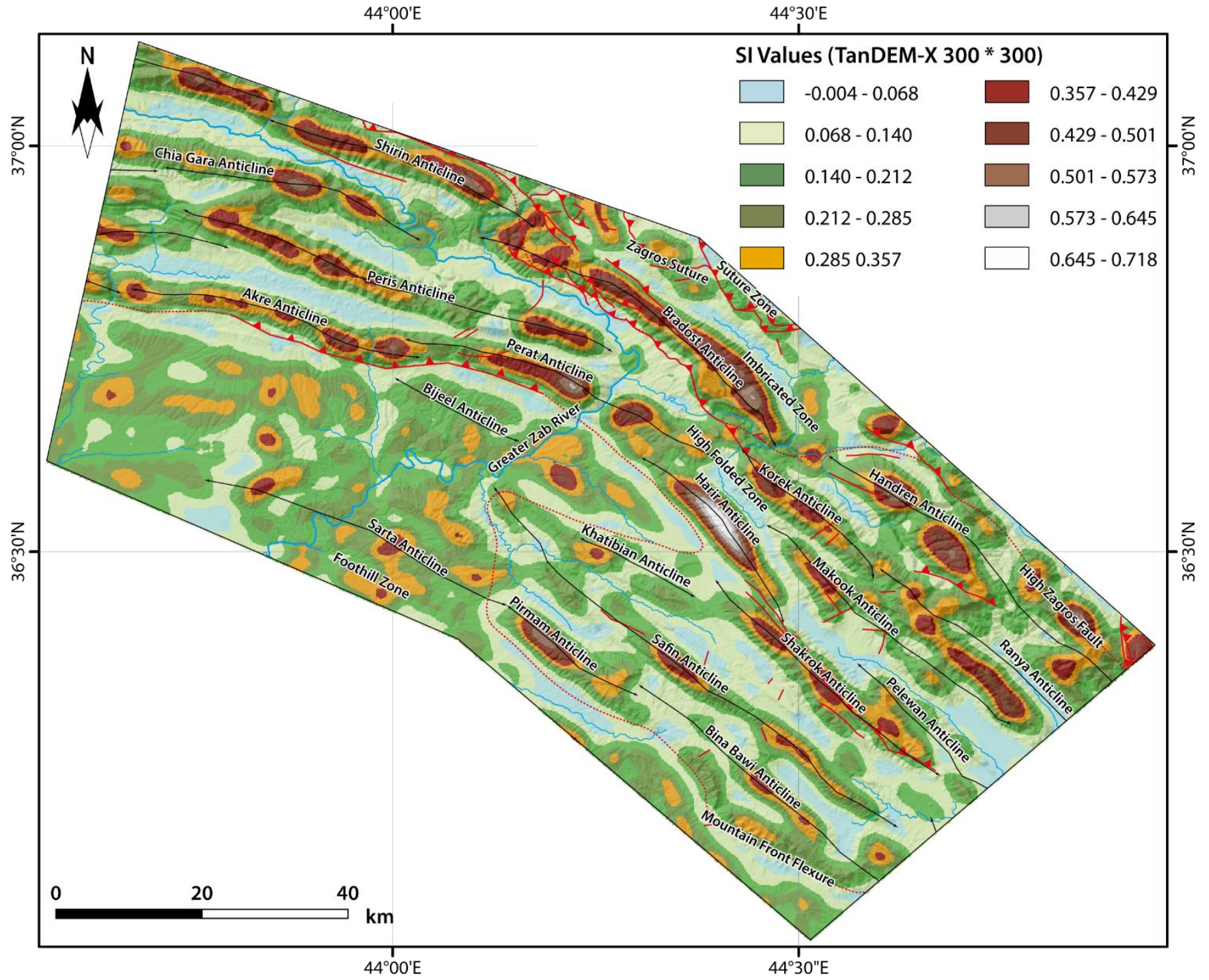

S15: Surface index $(\mathrm{SI})$ calculated for TanDEM-X with $300 * 300$ cell $(3.6 * 3.6 \mathrm{~km})$ moving window. 


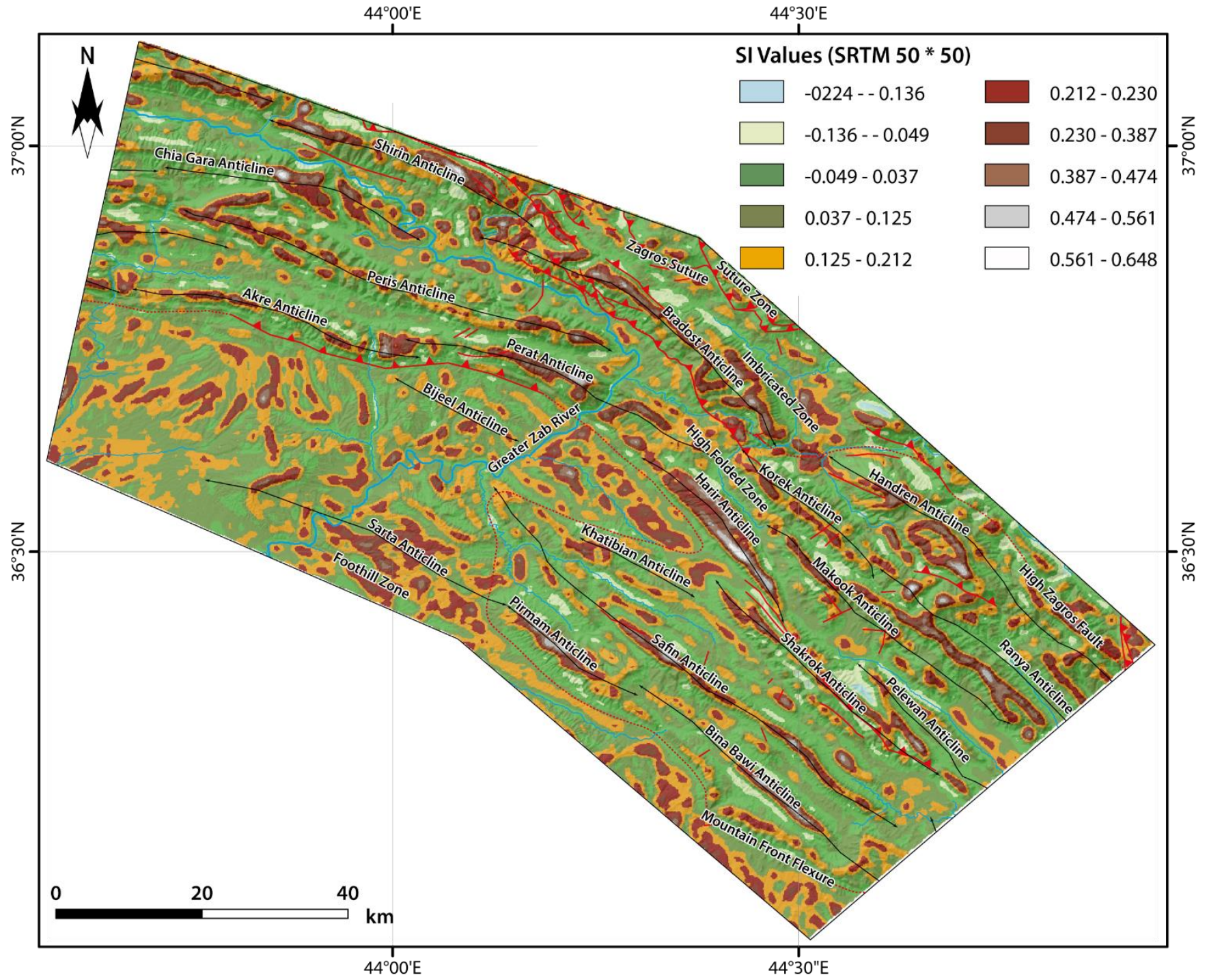

S16: Surface index $(\mathrm{SI})$ calculated for SRTM with $50 * 50$ cell $(1.5 * 1.5 \mathrm{~km})$ moving window. 


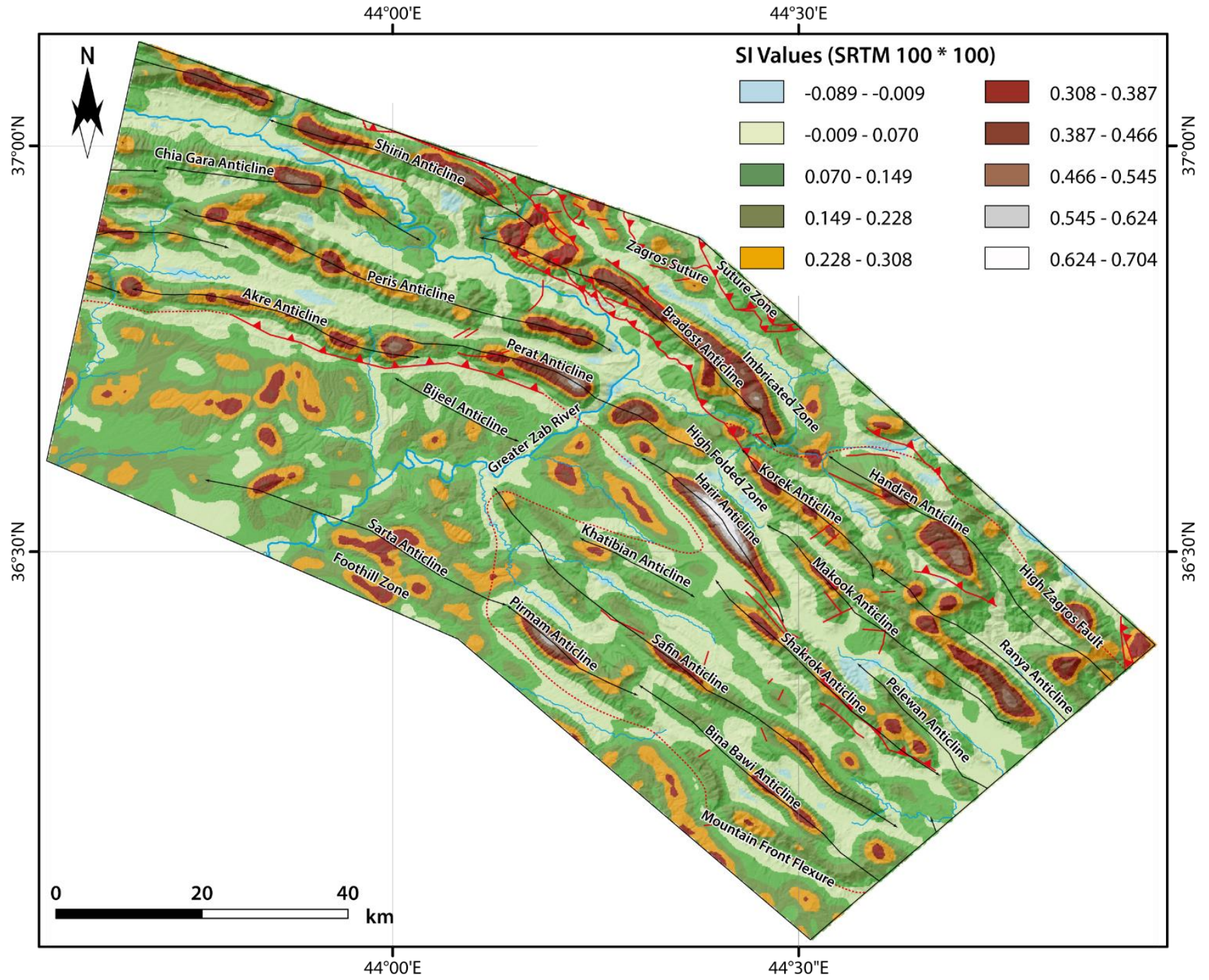

S17: Surface index (SI) calculated for SRTM with $100 * 100$ cell $(3 * 3 \mathrm{~km})$ moving window. 


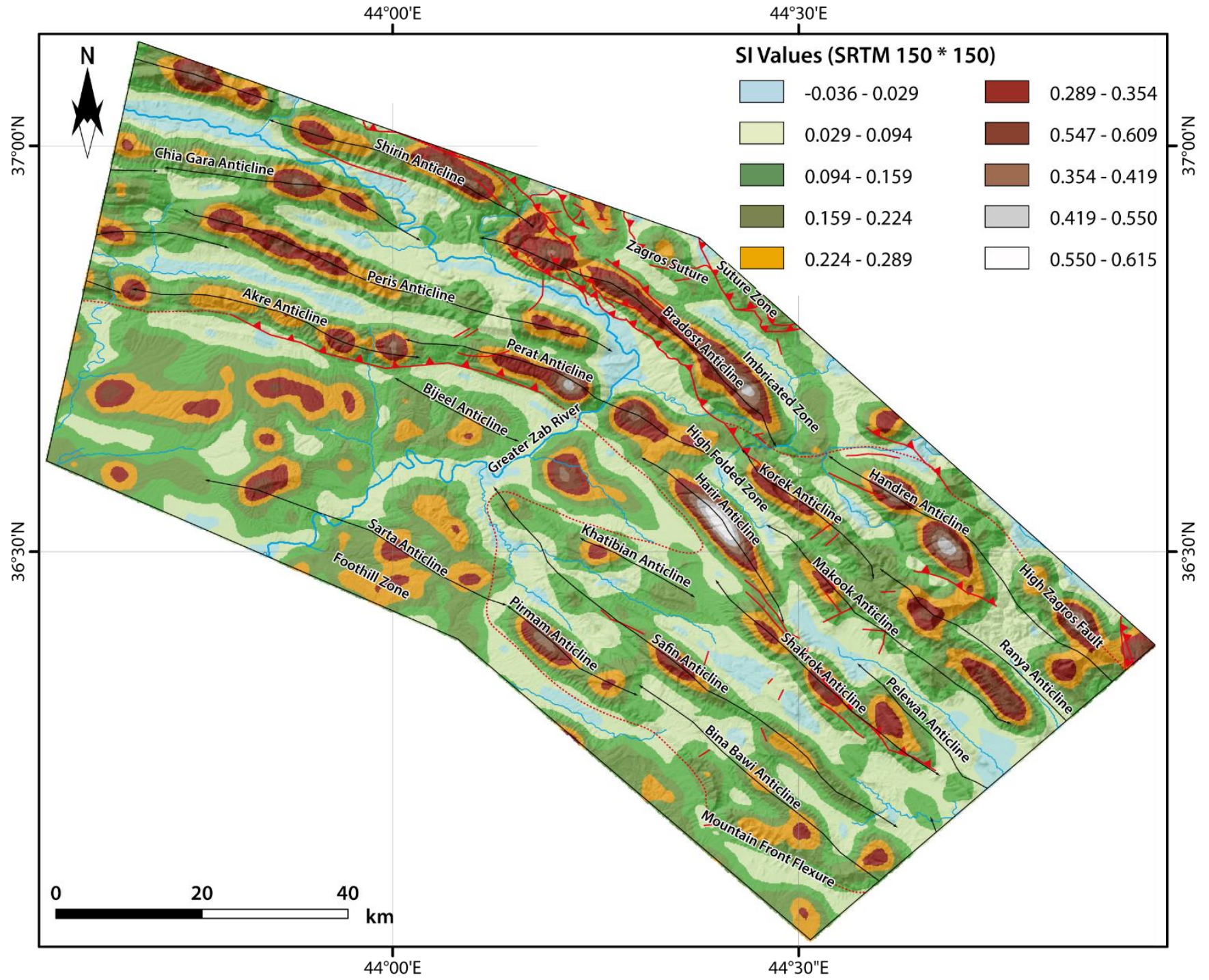

S18: Surface index $(\mathrm{SI})$ calculated for SRTM data with $150 * 150$ cell $(4.5 * 4.5 \mathrm{~km})$ moving window. 


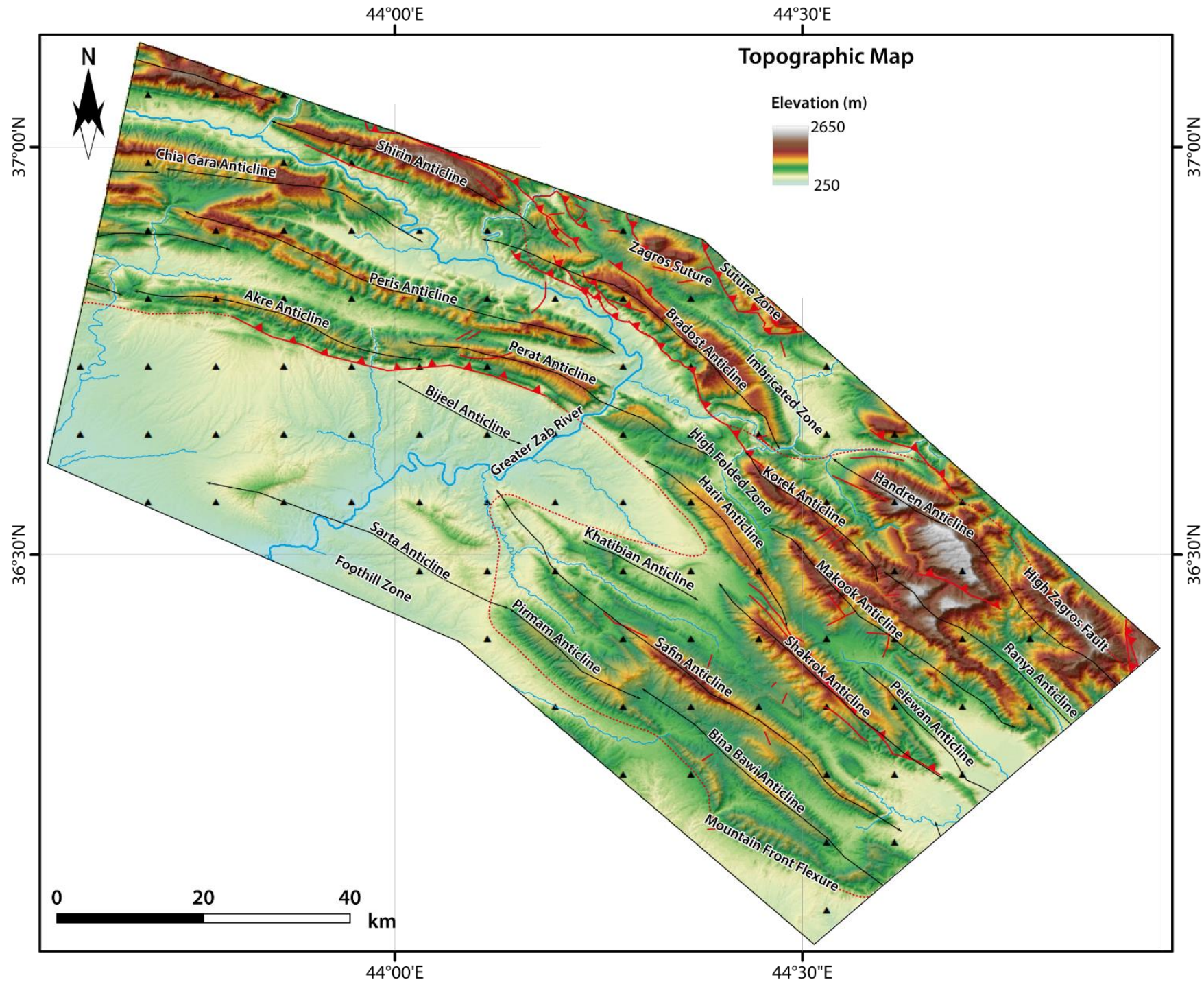

S19: Topographic map of the study area obtained from SRTM1 (30 m resolution data) showing tectonic structures. Triangles indicate points used for comparison of geomorphic indices from different data sets (TanDEM-X vs. SRTM1) and different size of moving windows. 

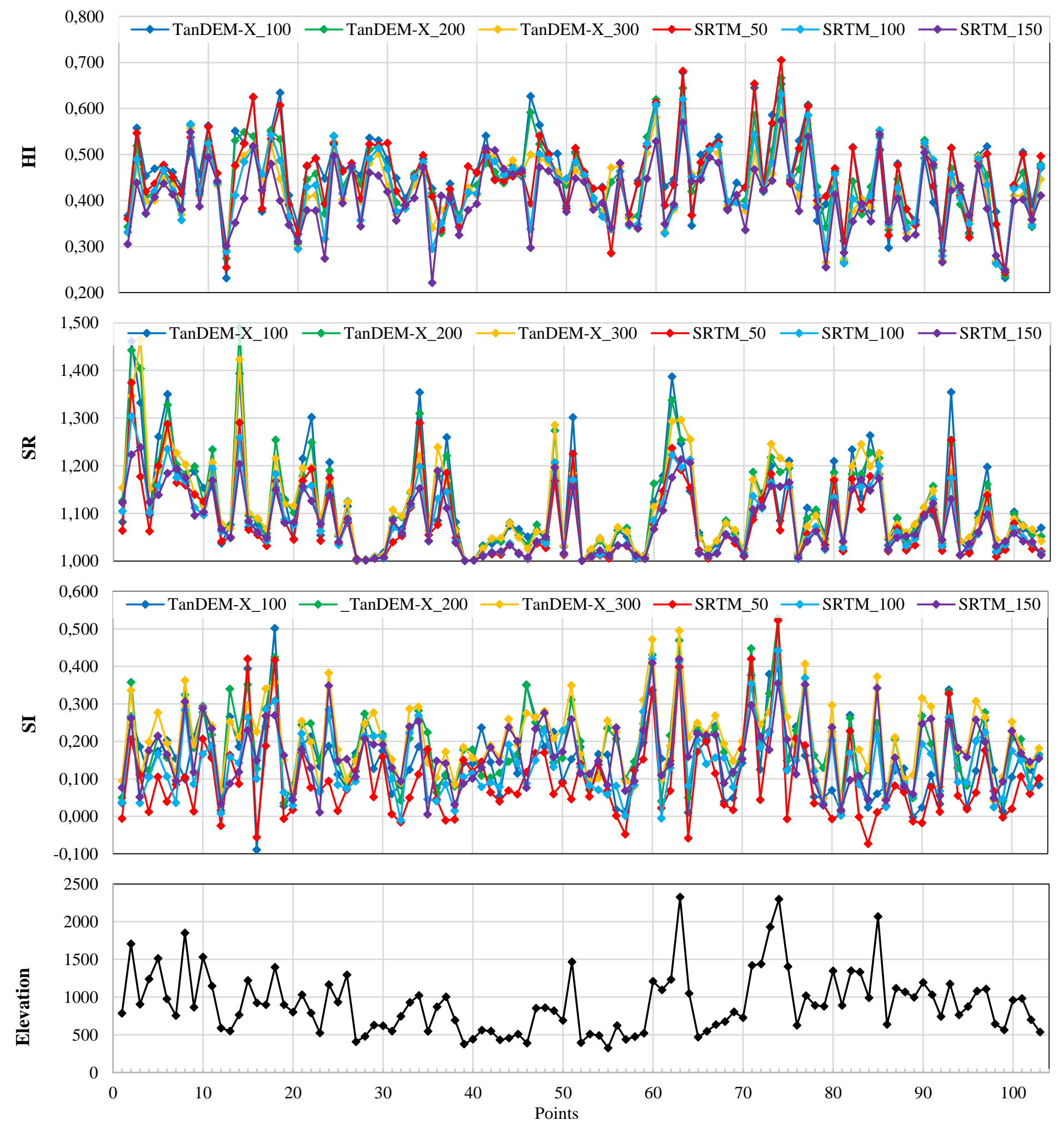
S20: Comparison of geomorphic indices obtained from different input DEM's (TanDEM-X and SRTM1) and different size of moving window for 103 points in the area with $7.5 \mathrm{~km}$ spacing in between them.

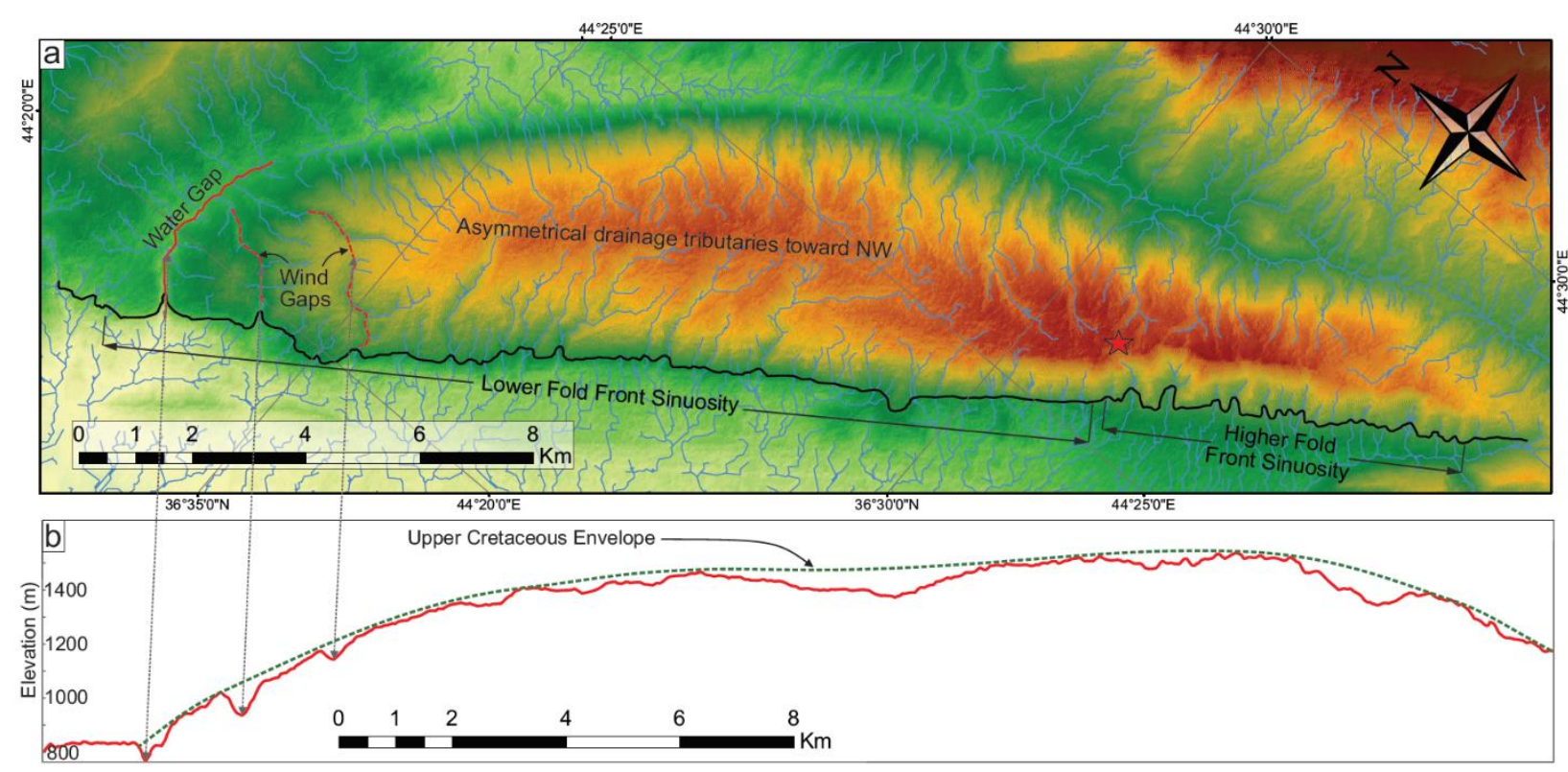

5 S21: Lateral growth of the Harir Anticline NW-ward along the Mountain Front Flexure as indicated from several geomorphic criteria. The criteria include wind and water gaps, asymmetrical drainage tributaries and the quantification of the relative fold front sinuosity. The combination of a conspicuously low fold front sinuosity in the NW part of the structure and successive wind gaps and water gaps suggest ongoing lateral and vertical growth of the fold above underlying faults. Figure modified from Zebari and Burberry (2015).

10

\section{Reference:}

Zebari, M. M. and Burberry, C. M.: 4-D evolution of anticlines and implications for hydrocarbon exploration within the Zagros Fold- Thrust Belt, Kurdistan Region, Iraq, GeoArabia, 20(1), 161-188, 2015. 